\title{
Factors associated with iron deficiency anemia in Brazilian preschool children
}

\author{
Fatores associados a anemia por deficiência de ferro em crianças pré-escolares brasileiras \\ Carlos A. N. de Almeida¹, Rubens G. Ricco², Luiz A. Del Ciampo³, \\ Ana M. Souza4 ${ }^{4}$ Adriana P. Pinho5, José E. Dutra de Oliveira6
}

Nota: a versão completa em português deste artigo está disponível em www.jped.com.br

\begin{abstract}
Objective: To examine the determining factors of anemia and iron deficiency in children attending two day care centers in the town of Pontal, southeast of Brazil.

Methods: Cross-sectional study was conducted in 192 children aged 12 to 72 months. Personal data (age, sex, use of medicinal iron supplements, duration of breast-feeding, type of delivery, prenatal care, weight, and height), and socioeconomic data (number of coinhabitants, parental schooling, and per capita family income) were obtained and evaluated together with hemoglobin, serum transferrin receptor, ferritin, and iron deficiency anemia.
\end{abstract}

Results: Age was the variable that most affected iron nutritional status, with higher hemoglobin values, lower transferrin receptor concentrations, higher ferritin values and lower iron deficiency anemia being detected with increasing age. The other studied variables did not show any correlation with iron nutritional status.

Conclusion: The obtained data suggest that control strategies for this preschool population should be especially directed at younger children.

J Pediatr (Rio J). 2004;80(3):229-34: Anemia, iron deficiency, children.

\section{Introduction}

Iron deficiency is considered one of the most prevalent nutritional disorders worldwide, affecting more than two billion people. ${ }^{1}$ Several studies have demonstrated that in

1. PhD; Professor, Universidade de Ribeirão Preto, Ribeirão Preto, SP, Brazil. Director of the Department of Pediatric Nutritional Studies, Associação Brasileira de Nutrologia (ABRAN).

2. Professor, School of Medicine of Ribeirão Preto, Universidade de São Paulo (USP), Ribeirão Preto, SP, Brazil.

3. PhD; Professor, School of Medicine of Ribeirão Preto, Universidade de São Paulo (USP), Ribeirão Preto, SP, Brazil.

4. Professor, School of Pharmaceutics of Ribeirão Preto, Universidade de São Paulo (USP), Ribeirão Preto, SP, Brazil.

5. MSc; Chief of the Laboratory of Clinical Studies, Universidade de Ribeirão Preto, Ribeirão Preto, SP, Brazil.

6. Former professor, School of Medicine of Ribeirão Preto, Universidade de São Paulo (USP), Ribeirão Preto, SP, Brazil.

Manuscript received Jul 28 2003, accepted for publication Mar 032004.

\section{Resumo}

Objetivo: Avaliar fatores determinantes de anemia e deficiência de ferro em crianças das duas creches da cidade de Pontal, sudeste do Brasil.

Métodos: Estudo transversal foi realizado avaliando-se 192 crianças com idades entre 12 e 72 meses. Dados pessoais (idade, sexo, uso de ferro medicamentoso, duração do aleitamento materno, tipo de parto, cuidados pré-natais, peso e estatura) e dados sócio-econômicos (número de co-habitantes, escolaridade dos pais e renda per capita familiar) foram obtidos e correlacionados com hemoglobina, receptores de transferrina, ferritina e anemia ferropriva.

Resultados: A idade foi a variável mais afetada pelo estado nutricional de ferro, correlacionando-se com maiores valores de hemoglobina e ferritina e menores valores de receptor de tranferrina, sendo que menos anemia ferropriva foi detectada quanto maior a idade. As outras variáveis estudadas não apresentaram correlação com o estado nutricional de ferro.

Conclusão: Os dados sugerem que as estratégias de controle para essa população de crianças pré-escolares devem ser direcionadas especialmente para aquelas de menor idade.

J Pediatr (Rio J). 2004;80(3):229-34: Anemia, deficiência de ferro, crianças.

children, especially those under the age of five, iron deficiency anemia (IDA) is related, among other alterations, to low scores in mental development and motor activity tests, a fact that may lead to irreversible sequelae even in the presence of adequate treatment. 2,3

Despite the lack of comprehensive national studies, regional data have shown a substantial increase in the prevalence of anemia in Brazil, with this increase being observed among both males and females, from all age groups and all socioeconomic levels of the population. 4

Ultimately iron deficiency and anemia are due to a negative iron balance in the organism. Despite the apparent simplicity of the model, few advances have been made in terms of reducing IDA prevalence, probably due to the fact that this negative balance is the final result of a series of biosocioeconomic-cultural factors acting on the child. For 
example, in contrast to the low global prevalence of childhood anemia, the prevalence of IDA in children living at the periphery of large cities in the United States was found to be similar to that observed for developing countries. ${ }^{5}$ In addition, several studies have shown a clear correlation between iron deficiency and anemia and a series of determinants, such as a high number of co-inhabitants, 6,7 low educational level of the mother, ${ }^{8}$ high incidence of cesarean section, ${ }^{8}$ low educational level of the father, ${ }^{9}$ low per capita family income, 7,10 and poor general socioeconomic conditions. ${ }^{11}$ Thus, an understanding of the risk factors for each population is fundamental in order to provide efficient preventive and control measures. Within this context, the aim of the present study was to investigate the determining factors of anemia and iron deficiency among low-income preschool children who attend full-time public day care center, in order to provide a more detailed knowledge of the problem and to produce directives for a management program that is not only directed at the studied population, but also at populations with similar epidemiological characteristics.

\section{Patients and methods}

The study was carried out in the town of Pontal, state of São Paulo, southeast of Brazil, from July 1 to December 31, 1999. The study population was comprised of 225 children, aged 12 months (completed) to 72 months (incompleted) who attended two public day care centers: Creche São Pedro and Centro de Convivência Infantil (CCI). Excluded from the study were children who presented acute disease during the last two weeks preceding the study ( 23 children); children with diagnosed chronic diseases such as asthma, diabetes, collagen disease and heart disease (12 children), which might interfere with growth or lead to deformities that would impair the anthropometric measurements (two children); children with known hematological diseases except for IDA (four children); children on iron medication at the time of or 30 days prior to material collection (eight children), and children with a history of prematurity or low birth weight (14 children). After selection, 192 children were included in the study. The two day care centers in the municipality receive a low-income population, with both parents working outside home so that their children have to be cared for at full-time institution.

Personal and family data were obtained from each child on a single occasion by interviewing the parents or responsible persons. Weight and height were measured with an adequate apparatus, which was properly calibrated using accurate, internationally accepted techniques. ${ }^{12}$ Weight-for-age, weight-for-height and height-for-age $\mathrm{z}$ scores were determined for each child according to the recommendations of the World Health Organization. ${ }^{13,14}$ Venous blood was collected on the same day as the anthropometric measurements. Hemoglobin was determined with a Coulter T-890 automatic cell counter (series 6704465, New York, USA), serum ferritin was measured by an enzyme-linked fluorescent assay (ELFA) using the BIO-MÉRIEUX MiniVidas model (series SV 122588, Missouri, USA), transferrin receptor levels were determined by an immunoenzyme assay (Quantikine DVD kit, R\&D Systems Minneapolis, USA), with absorbance being read in an ELISA microplate Reader 210 coupled to a Washer 200-Microwell System (Organon Teknica, Austria), and red blood cells were analyzed using the sickling test (sodium metabisulfite method) for differential diagnosis with sickle cell anemia.

The response variables were hemoglobin, transferrin receptor, ferritin and IDA. Children showing hemoglobin levels below the cut-off point associated with increased transferrin receptor and/or reduced ferritin levels were considered to have IDA. The explanatory variables were divided into two groups:

1) quantitative explanatory variables: age, weight-forage $z$ score, weight-for-height $z$ score and height-for-age $z$ score;

2) qualitative explanatory or categorized quantitative variables: day care center (São Pedro or CCI), sex (male or female), prenatal care during pregnancy (yes or no), number of co-inhabitants (less than 4 or 4 or more), educational level of the father (illiterate or some schooling), educational level of the mother (illiterate or some schooling), previous treatment with iron salt (yes or no), type of delivery (normal or cesarean section), breastfeeding (exclusive: breast milk with no other foods or liquids; predominant: breast milk with other liquids as water or fruit juices but not milk or complementary foods; complemented: breast milk with complementary foods or liquids) ${ }^{15}$ or not (less than 2 months, 2 to 6 months, or more than 6 months), and monthly per capita family income (equal/more than R\$150.00).

Normality tests were carried out for each response variable (hemoglobin, ferritin and transferrin receptor) at each level of the nominal qualitative explanatory variables in order to choose the most adequate statistical procedure for data analysis. Since normality was rejected by various tests (at the $5 \%$ level of significance), nonparametric procedures were employed. ${ }^{16}$ The effects of the qualitative/ quantitative explanatory categorized variables on the response variables were determined using the Mann-Whitney and Kruskal-Wallis tests, with the level of significance set at $5 \%$. The effects of the quantitative explanatory variables on the response variables were evaluated using the Spearman correlation coefficient, followed by the association test, with the level of significance set at $5 \%$.

Logistic regression analysis was used to determine the influence of explanatory variables on IDA. All children with anemia and, at least, one positive indicator of iron deficiency have been included ( $\mathrm{hb}<11 \mathrm{mg} / \mathrm{dl}$ and ferritin $<12 \mathrm{ng} / \mathrm{ml}$ and/or transferrin receptor $>28 \mathrm{nmol} / \mathrm{ml}$ ). Univariate analysis was used first (at the $5 \%$ level of significance) to assess the independent effect of each variable on IDA and than (at the $20 \%$ level of significance) to determine the variables for the multivariate analysis. ${ }^{17}$

The study was approved by the Medical Research Ethics Committee of the University Hospital, School of Medicine of Ribeirão Preto, Universidade de São Paulo. 


\section{Results}

The prevalence of anemia (192 children evaluated, $\mathrm{hb}<$ $11 \mathrm{mg} / \mathrm{dl}$ ) was $62.5 \%$. The prevalence of iron deficiency varied according to the indicator studied, being $24.2 \%$ on the basis of ferritin (132 children evaluated, ferritin $<12$ $\mathrm{ng} / \mathrm{ml}$ ), and $62.9 \%$ on the basis of transferrin receptors ( 124 children evaluated, transferrin receptor $>28 \mathrm{nmol} / \mathrm{ml}$ ). Among the 119 children submitted to all laboratory tests, proven iron deficiency anemia ( $\mathrm{hb}<11 \mathrm{mg} / \mathrm{dl}$ and ferritin $<12 \mathrm{ng} / \mathrm{ml}$ and/or transferrin receptor $>28 \mathrm{nmol} / \mathrm{ml}$ ) was present in $51.3 \%$ of cases.

Tables 1 and 2 show the effects of the individually analyzed explanatory variables on the response variables. The day care center, at which the child was enrolled, and sex did not influence hemoglobin, ferritin or transferrin receptor values, thus permitting the analysis of boys and girls from the two institutions as a whole for the remaining explanatory variables. Only age showed a positive correlation with hemoglobin and ferritin concentrations and a negative correlation with transferrin receptor levels.

Table 3 shows the number of children for each analysis (n) and the $p$ value obtained upon univariate logistic regression analysis used to determine the influence of the explanatory variables on IDA. A significant (0.05) effect was only observed for age $(p=0.03)$, with younger children showing higher probability of been anemic.

Table 4 shows the $p$ values obtained upon multiple logistic regression analysis. In this case, 163 children, for whom complete observations had been obtained for all variables with $p$ values $<0.2$ (Table 3 ). At the level of significance established (alpha $=0.05$ ), the results corroborated those obtained by univariate analysis, i.e., age was the only variable that had a significant effect on IDA.

Table 1 - Percentiles (25, 50 and 75) of hemoglobin, transferrin receptor and ferritin and $p$ value at each level of the qualitative variables

\begin{tabular}{|c|c|c|c|c|c|c|c|c|c|c|c|c|c|c|c|c|}
\hline \multirow[t]{2}{*}{ Variable } & \multirow[t]{2}{*}{ Category } & \multicolumn{5}{|c|}{ Hemoglobin } & \multicolumn{5}{|c|}{ Transferrin receptor } & \multicolumn{5}{|c|}{ Ferritin } \\
\hline & & $\mathbf{n}$ & P25 & P50 & P75 & $\mathbf{p}$ & $\mathbf{n}$ & P25 & P50 & P75 & $\mathbf{p}$ & $\mathbf{n}$ & P25 & P50 & P75 & $\mathbf{p}$ \\
\hline \multirow{2}{*}{$\begin{array}{l}\text { Day care } \\
\text { center }\end{array}$} & São Pedro & 84 & 10.4 & 10.9 & 11.4 & & 55 & 27.3 & 35.0 & 43.1 & & 58 & 10.0 & 24.9 & 41.8 & \\
\hline & $\mathrm{CCI}$ & 108 & 10.2 & 10.9 & 11.6 & 0.90 & 69 & 25.8 & 32.5 & 39.0 & 0.25 & 74 & 12.4 & 20.0 & 32.9 & 0.65 \\
\hline \multirow[t]{2}{*}{ Sex } & Female & 87 & 10.4 & 10.9 & 11.6 & & 60 & 26.0 & 32.5 & 39.6 & & 61 & 12.4 & 25.4 & 37.4 & \\
\hline & Male & 105 & 10.3 & 11 & 11.4 & 0.89 & 64 & 26.1 & 34.2 & 41.7 & 0.55 & 71 & 11.6 & 20.5 & 34.1 & 0.54 \\
\hline \multirow[t]{2}{*}{ Prenatal care } & Yes & 143 & 10.3 & 10.9 & 11.4 & & 93 & 25.6 & 32.5 & 40.3 & & 100 & 12.2 & 23.1 & 34.3 & \\
\hline & No & 13 & 10.6 & 11 & 11.7 & 0.47 & 8 & 26.5 & 36.6 & 42.7 & 0.68 & 8 & 10.2 & 23.0 & 34.6 & 0.77 \\
\hline \multirow{2}{*}{$\begin{array}{l}\text { Number of } \\
\text { co-inhabitants }\end{array}$} & Less than 4 & 26 & 10.1 & 10.9 & 11.3 & & 15 & 23.9 & 39.0 & 55.8 & & 16 & 8.9 & 14.2 & 26.9 & \\
\hline & 4 or more & 160 & 10.4 & 11 & 11.6 & 0.17 & 107 & 26.3 & 32.5 & 40.0 & 0.42 & 114 & 12.2 & 23.1 & 36.5 & 0.09 \\
\hline \multirow{2}{*}{$\begin{array}{l}\text { Father's } \\
\text { educational } \\
\text { level }\end{array}$} & Illiterate & 30 & 10.5 & 11.1 & 11.4 & & 20 & 26.1 & 39.1 & 51.1 & & 19 & 8.9 & 19.6 & 30.6 & \\
\hline & $\begin{array}{l}\text { Some } \\
\text { schooling }\end{array}$ & 146 & 10.3 & 10.9 & 11.4 & 0.49 & 96 & 26.3 & 33.5 & 39.6 & 0.20 & 105 & 12.2 & 21.2 & 37.4 & 0.17 \\
\hline \multirow{2}{*}{$\begin{array}{l}\text { Mother's } \\
\text { educational } \\
\text { level }\end{array}$} & Illiterate & 26 & 10.3 & 10.7 & 11.3 & & 16 & 25.2 & 40.1 & 48.5 & & 16 & 7.1 & 15.9 & 30.4 & \\
\hline & $\begin{array}{l}\text { Some } \\
\text { schooling }\end{array}$ & 160 & & & 11.6 & 0.28 & 106 & 26.3 & 32.5 & 39.1 & 0.12 & 114 & 12.4 & 21.9 & 35.4 & 0.13 \\
\hline \multirow{2}{*}{$\begin{array}{l}\text { Previous } \\
\text { treatment }\end{array}$} & No & 96 & 10.2 & 10.9 & 11.4 & & 59 & 26.3 & 32.5 & 45.6 & & 60 & 11.6 & 3 & 35.2 & \\
\hline & Yes & 96 & 10.4 & 11 & 11.5 & 0.30 & 65 & 25.6 & 33.8 & 40.0 & 0.43 & 72 & 12.2 & 20.7 & 33.1 & 0.76 \\
\hline \multirow{2}{*}{$\begin{array}{l}\text { Type of } \\
\text { delivery }\end{array}$} & Normal & 112 & 10.3 & 11 & 11.6 & & 73 & 25.8 & 33.6 & 41.1 & & 79 & 12.2 & 22.6 & 36.5 & \\
\hline & Cesarean & 70 & 10.4 & 10.9 & 11.4 & 0.52 & 44 & 26.2 & 31.7 & 39.3 & 0.64 & 47 & 11.4 & 20.8 & 32.9 & 0.52 \\
\hline \multirow[t]{2}{*}{$\begin{array}{l}\text { Per capita } \\
\text { family } \\
\text { income }\end{array}$} & $\begin{array}{l}\text { U\$ } 50.00 \\
\text { or more } \\
\text { Less than }\end{array}$ & 57 & 10.4 & 10.9 & 11.6 & & 42 & 27.2 & 34.4 & 42.3 & & 42 & 9.8 & 21.0 & 31.7 & \\
\hline & $U \$ 50.00$ & 129 & 10.4 & 11 & 11.4 & 0.71 & 80 & 25.8 & 32.5 & 40.0 & 0.44 & 88 & 12.1 & 22.4 & 37.0 & 0.32 \\
\hline \multirow{3}{*}{$\begin{array}{l}\text { Duration of } \\
\text { breast- } \\
\text { feeding }\end{array}$} & Less than $2 \mathrm{~m}$ & 60 & 10.4 & 10.9 & 11.5 & & 43 & 26.4 & 34.2 & 41.1 & & 43 & 11.2 & 19.6 & 34.4 & \\
\hline & 2 to $6 \mathrm{~m}$ & 62 & 9.7 & 10.8 & 11.3 & & 39 & 25.6 & 32.5 & 45.6 & & 42 & 11.6 & 24.8 & 45.3 & \\
\hline & More than $6 \mathrm{~m}$ & 66 & 10.7 & 11.1 & 11.7 & 0.08 & 40 & 25.8 & 31.7 & 40.0 & 0.79 & 45 & 12.9 & 22.6 & 34.1 & 0.83 \\
\hline
\end{tabular}


Table 2 - Spearman correlation coefficient and $p$ values obtained by the association test between the quantitative explanatory variables and the response variables hemoglobin, transferrin receptor and ferritin

\begin{tabular}{lcccccc}
\hline Variable & \multicolumn{2}{c}{ Hemoglobin } & \multicolumn{2}{c}{ Transferrin receptor } & \multicolumn{2}{c}{ Ferritin } \\
& Coefficient & $\mathbf{p}$ & Coefficient & $\mathbf{p}$ & Coefficient & p \\
\hline Age & 0.11 & $<0.01$ & -0.62 & $<0.01$ & 0.30 & $<0.01$ \\
Weight-for-age z score & 0.05 & 0.48 & -0.04 & 0.67 & -0.02 & 0.86 \\
Weight-for-height z score & -0.04 & 0.63 & 0.05 & 0.60 & 0 & 0.96 \\
Height-for-age z score & 0.06 & 0.40 & -0.01 & 0.88 & -0.03 & 0.71 \\
\hline
\end{tabular}

Table 3 - Effect of independent variables on iron deficiency anemia determined by univariate logistic regression analysis

\begin{tabular}{lcc}
\hline Variable & n & p \\
\hline Day care center & 173 & 0.56 \\
Sex & 173 & 0.75 \\
Prenatal care & 139 & 0.44 \\
Number of co-inhabitants & 167 & $0.08 *$ \\
Father's educational level & 158 & 0.98 \\
Mother's educational level & 167 & 0.23 \\
Previous treatment & 173 & 0.89 \\
Type of delivery & 163 & 0.72 \\
Per capita family income & 167 & 0.79 \\
Duration of breast-feeding & & \\
(2 to 6 months) & 169 & $0.08 *$ \\
Duration of breast-feeding & & \\
(more than 6 months) & 169 & $0.07 *$ \\
Age & 173 & 0.03 \\
Weight-for-age z score & 173 & 0.78 \\
Weight-for-height z score & 173 & 0.24 \\
Height-for-age z score & 173 & 0.34
\end{tabular}

${ }^{*} p<0.20 \quad+p<0.05$

\section{Discussion}

The determination of factors that influence the occurrence and maintenance of anemia and iron deficiency in a population is fundamental for the implementation of control measures. Although the present study was conducted on a specific population, it is possible to extrapolate the data obtained here to developing countries and to low-income subpopulations in developed countries under similar socioeconomic conditions.

Among the factors analyzed, only age exerted an influence on all iron nutritional status indicators studied. With respect to hemoglobin concentration, the same trend was observed in other studies carried out under different conditions. ${ }^{18-21}$
Nicklas et al., ${ }^{22}$ studying preschool children in Haiti, observed a correlation between hemoglobin and age and suggested that children are able to consume a more varied diet with increasing age, thus improving their hematological indicators. The correlation observed between age and transferrin receptor levels, with these levels decreasing with increasing age, demonstrates increased tissue availability of iron in older children. With respect to ferritin, Nicklas et al. ${ }^{22}$ also observed increased ferritin values with increasing age in Haitian children aged two to five years. The correlation between age and IDA in fact permits us to suppose that younger children have a higher probability of manifesting the whole spectrum of iron deficiency, ranging from a decline in iron reserves to iron deficiency anemia. On the other hand, it is fundamental to continue the discussion about reference values and the eventual need of adjusting them to age, a requirement that can only be satisfied with studies determining clinical-laboratory correlations.

With respect to the other variables studied, previous iron treatment, although present in half the children, did not influence iron status. Based on the known fact that the recovery of deficiency indicators follows the inverse order of depletion, i.e., recovery of hemoglobin occurs first while ferritin recovery is last, previous iron therapy would be expected to lead to higher hemoglobin concentrations, but this was not the case. Mahu et al., ${ }^{23}$ studying 384 children from Réunion aged less than six years, also did not find any effect of previous iron therapy on hemoglobin

Table 4 - Effect of different variables on iron deficiency anemia determined by multiple logistic regression analysis

\begin{tabular}{ll}
\hline Variable & $\mathbf{p}$ \\
\hline Number of co-inhabitants & 0.12 \\
Duration of breast-feeding (2 to 6 months) & 0.32 \\
Duration of breast-feeding (more than 6 months) & 0.06 \\
Age & $0.04 *$ \\
\hline
\end{tabular}

${ }^{*} p<0.05$ 
values. Roughead \& Hunt ${ }^{24}$ observed that supplementation with medicinal iron reduces the absorption of non-heme iron from the diet in adults, a fact that in many cases nullifies its beneficial effect on iron reserves. On the other hand, this observation might indicate that oral iron therapy in the way usually performed in Brazil, i.e., daily doses of iron salt, is not sufficient to combat anemia and iron deficiency. In fact, several authors have demonstrated that the high incidence of side effects nearly always leads to poor compliance with this type of treatment. 25,26

Studies carried out in different parts of the world have shown conflicting results regarding the correlation between anemia and anthropometric indicators. De Almeida et al. 27 did not find any influence of the $z$ scores of anthropometric measurements on hemoglobin values, although it should be noted that the study population showed low prevalence of undernutrition and obesity. In contrast, O'Donnell et al., ${ }^{8}$ studying deprived preschool children from Buenos Aires, observed a correlation between anemia and a low height-for-age $z$ score. In fact, no correlation has been observed between anemia and anthropometric indicators among populations with adequate nutritional status. ${ }^{7,23}$

According to the current model, ferritin, the iron reserve in the organism, is the first compartment to be depleted in the case of a negative iron balance. ${ }^{28}$ One would therefore assume that the determinants assessed here exert a greater effect on this variable than on the other parameters studied, but this was not the case. In fact, other authors have observed correlations between ferritin and different variables such as body weight, ${ }^{29}$ low social class, ${ }^{30}$ and sex. ${ }^{31}$ The evaluation of the effect of the time of use of maternal milk on ferritin would be of particular interest. In the present study, no difference was observed between the three groups studied. Innis et al. 32 observed that breast-feeding resulted in lower ferritin levels in Canadian children, irrespective of its duration. Hokama ${ }^{33}$ found lower ferritin levels in Japanese children who were exclusively breast-feed compared to those receiving milk from other sources as complementation. Several studies, such as those of Saarinen ${ }^{34}$ in Turkey, Pastel et al. ${ }^{35}$ in Peruvian children and Franco et al. ${ }^{36}$ in Chile, have demonstrated that [even] exclusive breastfeeding is able to maintain adequate iron reserves, represented by satisfactory ferritin levels, until at least six months of age. The data obtained in the present study showed no correlation between iron nutritional status and short- or long-term breast-feeding for the age group studied. Various limitations should be taken into account when interpreting this result. The main limitation was the fact that, in the breast-feeding group we did not discriminate between exclusive and non-exclusive, but only considered the effect of breast-feeding as a good iron source for the child. Another possible bias was the fact that all age groups were analyzed as a whole, which might have diluted the effect of the variable at the time when younger, recently weaned children were analyzed together with other much older children who had already been submitted to different diets during life.
In contrast to other deprivation diseases in which control strategies always comprise intervention within the socioeconomic context, the obtained data indicate more objective and feasible approaches for the population studied. Specifically, effort and financial resources should be concentrated on the implementation of measures aiming at increasing the iron supply, especially for younger children, through medication and fortification of habitually consumed foods. Similarly, other countries, especially developing countries, that were able to control protein-calorie malnutrition but that continue to show high prevalence of anemia, may require similar strategies for the control of this highly important world public health problem.

\section{References}

1. Layrisse M, Cháves JF, Mendez-Castellano H, Bosch V, Tropper $E$, Bastardo B, et al. Early response to the effect of iron fortification in the Venezuelan population. Am J Clin Nutr. $1996 ; 64: 903-7$.

2. Osky FA. The nonhematologic manifestations of iron deficiency. Am J Dis Child. 1979;133:315-22.

3. Lozoff B, Wolf AW, Jimenez E. Iron-deficiency anemia and infant development: effects of extended oral iron therapy. J Pediatr. 1996; 129:382-9.

4. Monteiro CA, Szarfarc SC, Mondini L. Tendência secular da anemia na infância na cidade de São Paulo (1984-1996). Rev Saúde Pública. 2000;34:62-72.

5. Booth IW, Aukett MA. Iron deficiency anemia in infancy and early childhood. Arch Dis Child. 1997;76:549-54.

6. Czajka-Narins DM, Haddy TB, Kallen DJ. Nutrition and social correlates in iron deficiency anemia. Am J Clin Nutr. 1978;31:955-60.

7. Neuman NA, Tanaka OU, Szarfarc SC, Guimarães PRV, Victora CG. Prevalência de fatores de risco para anemia no Sul do Brasil. Rev Saúde Pública. 2000;34:56-63.

8. O’Donnell A, Carmuega ES, Durán P. Preventing iron deficiency in infants and preschool children in Argentina. Nutr Rev. 1997; 55:189-94.

9. Nestel P, Melara A, Rosado J, Mora JO. Vitamin A deficiency and anemia among children 12-71 months old in Honduras. Rev Panam Salud Publica. 1999;6:34-43.

10. Romani SAM, Lira PIC, Batista Filho M, Sequeira LÃS, Freitas CLC. Anemias em pré-escolares: diagnóstico, tratamento e avaliação em Recife-PE, Brasil. Arch Latinoam Nutr. 1991;41:159-67.

11. Marx JJM. Iron deficiency in developed countries: prevalence, influence of lifestyle factors and hazards of prevention. Eur J Clin Nutr. 1997;51:491-4.

12. Cameron N. The measurement of human growth. London: Croom-Helm; 1984.

13. WHO Working Group on Infant Growth. An evaluation of infant growth: the use and interpretation of anthropometry in infants. Bull WHO. 1995;73:165-74.

14. Onis M, Habicht JP. Anthropometric reference data for international use: recommendations from a World Health Organization Expert Committee. Am J Clin Nutr. 1996;64:650-8.

15. WHO. Indicators for assessing breastfeeding practices. Geneva: WHO; 1991.

16. Hollander M, Wolfe DA. Nonparametric Statistical Methods. 2nd ed. New York: John Wiley \& Sons; 1973.

17. Hosmer DW, Lemeshow S. Applied Logistic Regression. New York: John Wiley \& Sons; 1989.

18. Hossain MM, Bakir M, Pugh RNH, Sheekh-Hussen M, Ishaq SAB, Berg DB, et al. The prevalence and correlates of anemia among young children and women of childbearing age in Al Ain, United Arab Emirates. Ann Trop Paed. 1995;15:227-35.

19. Assis AMO, Santos LMP, Martins MC, Araújo MPN, Amorin DQ, Morris SS, et al. Distribuição da anemia em pré-escolares do semi-árido da Bahia. Cad Saúde Pública (Rio de Janeiro). 1997;13:237-43. 
20. Cornet M, Hesran JY, Fievet N, Cot M, Personne P, Gounoue R, et al. Prevalence of and risk factors for anemia in young children in Southern Cameroon. Am J Trop Med Hyg. 1998;58:606-11.

21. Giebel HN, Suleymanova D, Evans GW. Anemia in young children of the Muynak District of Karakalpakistan, Uzbekistan: prevalence, type and correlates. Am J Public Health. 1998;88:805-7.

22. Nicklas TA, Kuvibidila S, Gatewood LC, Metzinger AB, Frempong KO. Prevalence of anemia and iron deficiency in urban Haitian children two to five years of age. J Trop Pediatr. 1998;44:133-8.

23. Mahu JL, Valteau D, Suquet JP, Meskens C, Saly JC, Lebas J. Prevalence and etiology of anemia in Reunion: comparative study of hematological, biochemical and anthropometric parameters, parasitic and clinical status of anemic and nonanemic children. Nutr Res. 1988;8:733-44.

24. Roughead ZK, Hunt JR. Adaptation in iron absorption: iron supplementation reduces nonheme-iron but not heme-iron absorption from food. Am J Clin Nutr. 2000;72:982-9.

25. Cardoso MA, Penedo MVC. Intervenções nutricionais na anemia. Cad Saúde Pública (Rio de Janeiro). 1994;10:231-40.

26. Batista Filho M, Ferreira LOC. Prevenção e tratamento da anemia nutricional ferropriva: novos enfoques e perspectivas. Cad Saúde Pública (Rio de Janeiro). 1996;12:411-5.

27. De Almeida CAN, Ricco RG, Del Ciampo LA, Souza AM, Dutra de Oliveira JE. Growth and hematological studies on Brazilian children of low socioeconomic level. Arch Latinoam Nutr. $2001 ; 51: 230-5$.

28. Expert Scientific Working Group. Summary of a report on assessment of the iron nutritional status of the United States population. Am J Clin Nutr. 1985;42:1318-30.

29. Dommergues JP, Breton MP, Ducot B, Yvart J, Rossignol C, Tchernia G. Iron deficiency in infants. Study of risk factors. Arch Fr Pediatr. 1984;41:623-7.
30. Mesanza PL, Martinez EO, Altuna MS, Frances MAP, Dolora MJU, Jimenez JLL. Anemia and depletion of iron reserves in healthy 12 month old infants. An Esp Pediatr. 1992;37:24-8.

31. Wharf SG, Fox TE, Fairweather-Tait SJ, Cook JD. Factors affecting iron stores in infants 4-18 months of age. Eur J Clin Nutr. 1997;51:504-9.

32. Innis SM, Nelson CM, Wadsworth LD, MacLaren IA, Lwanga D. Incidence of iron-deficiency anaemia and depleted iron stores among nine-month-old infants in Vancouver, Canada. Rev Canad Sant Pub. 1997;88:80-4.

33. Hokama T. Levels of serum ferritin and total iron among infants with different feeding regimens. Acta Paediatr Jpn. 1993;35:298-301.

34. Saarinen UM. Need for iron supplementation in infants on prolonged breast feeding. J Pediatr. 1978;93:177-80.

35. Pastel RA, Howanitz PJ, Osky FA. Iron sufficiency with prolonged exclusive breast-feeding in Peruvian infants. Clin Pediatr. $1981 ; 20: 625-6$.

36. Franco E, Hertrampf E, Rodriguez E, Illanes JC, Palácios L, Llaguno $S$, et al. Iron nutrition in Mapuche infants fed with human milk (2d phase). Rev Chil Pediatr. 1990;61:248-52.

Corresponding author:

Carlos Alberto Nogueira de Almeida

Rua Tamoios 262/154

CEP 14020-700 - Ribeirão Preto, SP

Tel/Fax: (16) 621.8130

E-mail: carlosnogueira@directnet.com.br 